blishment of normal performances (DMG $660 \mathrm{~g}$; liCR : 2.53), but addition of tryptophan (group 0 ) appeared not to be necessary. Is a matter of fact, tryptophan supplementation alone (group 5) secmed to create an imbalance by excess leading to growth depression (6I5 g/day) and deterioration of the feed conversion ratio $(2.65)$.

During the finishing period, between 60 and oo $\mathrm{kg}$ live weight, the results obtained did not significantly differ from one treatment to another, but the two best treatments during the growing period (group 2 and 6 ) also appeared to be the best ones during the finishing period.

As regards the total growing-finishing period, substitution of half of the soyabean protein by blood meal (group 2 versus group I) improved by 6 p. Ioo the growth rate and by 4 p. Ioo the feed conversion ratio. Likewise, total replacement of soybean oil-meal by a supply of r 2 p. roo blood meal, supplemented with isoleucine $(0.05 \mathrm{p}$. Ioo) and tryptophan (0.03 p. Ioo), improved by 4 p. Ioo the growth rate and by 5 p. Ioo the feed conversion ratio. With respect to body composition, no difference between the treatments was noticed.

This experiment shows the advantage of using blood meal as protein replacer of soyabean oil-meal for fattening pigs. In terms of French pig production, blood meal (around 50 ooo tons), used as a replacer of $50 \mathrm{p}$. I oo of the supplementary supply of protein, might ensure the fattening of 3 millions of pigs per year

\title{
Energy value of dried beet-pulps and utilization by the growing-finishing pig
}

J. CHAUVEL, J. VILLAIN-GUILLOT* and D. BOURDON**

\author{
Institut technique du Porc, \\ 149, rue de Bercy, \\ 75579 Paris Cedex 12 \\ * Établissement Départemental de l'Élevage de l'Oise, \\ 3 , rue du Palais de Justice, \\ 60000 Beauvais \\ ** Station de Recherches sur l'Illevage des Porcs, I. N. R. A., C. N.R.Z., \\ 78350 Jouy en Josas
}

\section{Energy value}

The study included I 2 pigs (castrated Large White males) from 28 to $37 \mathrm{~kg}$, divided into 3 groups kept in metabolism crates. Group I received a control diet (maize-soyabean); groups 2 and 3 were fed with $20 \mathrm{p}$. Ioo dricd beet pulps in replacement of the maize soyabean mixture. No differences were recorded in the growth performances (but the period was short and the number of animals small) however 20 p. Ioo pulps increased the feed conversion ratio by 3 p. Ioo. Digestibility decreased linearly when the crude fibre content increased (i.e. pulp level). The digestible energy of beet pulp represented $2562 \mathrm{kcal} / \mathrm{kg}$ dry matter, the apparent digestibility coefficient of energy being 60.4 p. Ioo.

\section{Utilization of dried beet-pulps}

The three treatments described above were compared on 30 pigs (Io per treatment) from 26 to $98 \mathrm{~kg}$ liveweight. Growth performances were only slightly changed at the level of ro p. IOO pulps but the daily mean gain decreased by $5 \mathrm{p}$. Ioo and the feed conversion ratio increased by 
I 3 p. Ioo at the level of 20 p. Ioo pulps; the carcass quality was markedly improved (smaller fat depot).

In conclusion, it is not advisable to exceed $20 \mathrm{p}$. Ioo dried beet pulps in growing-finishing pig diets.

\title{
Utilization of some crude fibre rich raw materials in the feeding of bacon pigs : oat, wheat bran, dried beet pulp
}

\author{
J. P. BOUARD and M. LEULLLET \\ Institut technique des Céréales et des Fourrages, \\ 8. Avenue du Président Wilson, \\ 75116 Paris
}

In our experimental conditions, the best feed efficiency and the most favourable growth performances have been obtained with diets including highly energetic cereals (maize and wheat) combined with soybean oil-meal. However, in the absence of a rigorous feeding schedule and especially in the case of "pre-fattening", the carcasses obtained exhibited large amounts of subcutaneous depot fats and were penalized by the commercial grading.

Dilution of the energy concentration by bulk feeds has been studied in some trials and the results obtained show the impact of the source of crude fibre or type of cereal used in the diet : maize (MOAL, 1971), wheat (HENRY et BOURDON, I97I) or barley (HENRY et al., 1970).

As most of these trials were made under semi-ad libitum feeding conditions, it was decided to repeat them in true ad libitum feeding conditions (pre-fattening), using a classical crude fibre source (wheat bran) or a less traditional one (dried beet pulp and oat).

These two trials show that it is not advisable to use crude fibre, at least not under conditions of pre-fattening after $55 \mathrm{~kg}$ or ad libitum feeding during the whole fattening period. The attempts made to noticeably reduce the fatness of the carcasses did not succeed with the type of pigs available, and the feed intake increased.

\section{Energy value and utilization \\ of two types of barley (regular and hulless) by the growing-finishing pig}

\author{
Y. HENRY and D. BOURDON \\ Station de Recherches sur l'ílevage des Porcs, I. N. R. A., C. N. R. Z., \\ 78350 Jouy en Josas
}

In order to compare the utilization of two types of barley, regular and hulless, by the growingfinishing pig, two experiments were performed :

-- the first experiment was made on 2 groups of 7 castrated male pigs in metabolism crates, at an average body weight of $39 \mathrm{~kg}$, with the aim of measuring the digestible (DE) and corrected metabolisable (MF,n) energy values of the two types of barley in relation with the level of crude fibre. 